This item was submitted to Loughborough's Research Repository by the author.

Items in Figshare are protected by copyright, with all rights reserved, unless otherwise indicated.

\title{
Public-private partnerships in the water and sanitation sector
}

PLEASE CITE THE PUBLISHED VERSION

PUBLISHER

(C) Thomas Telford Ltd

VERSION

VoR (Version of Record)

LICENCE

CC BY-NC-ND 4.0

REPOSITORY RECORD

Sohail, M., and Sue Cavill. 2019. "Public-private Partnerships in the Water and Sanitation Sector". figshare. https://hdl.handle.net/2134/5315. 
This item was submitted to Loughborough's Institutional Repository (https://dspace.lboro.ac.uk/) by the author and is made available under the following Creative Commons Licence conditions.

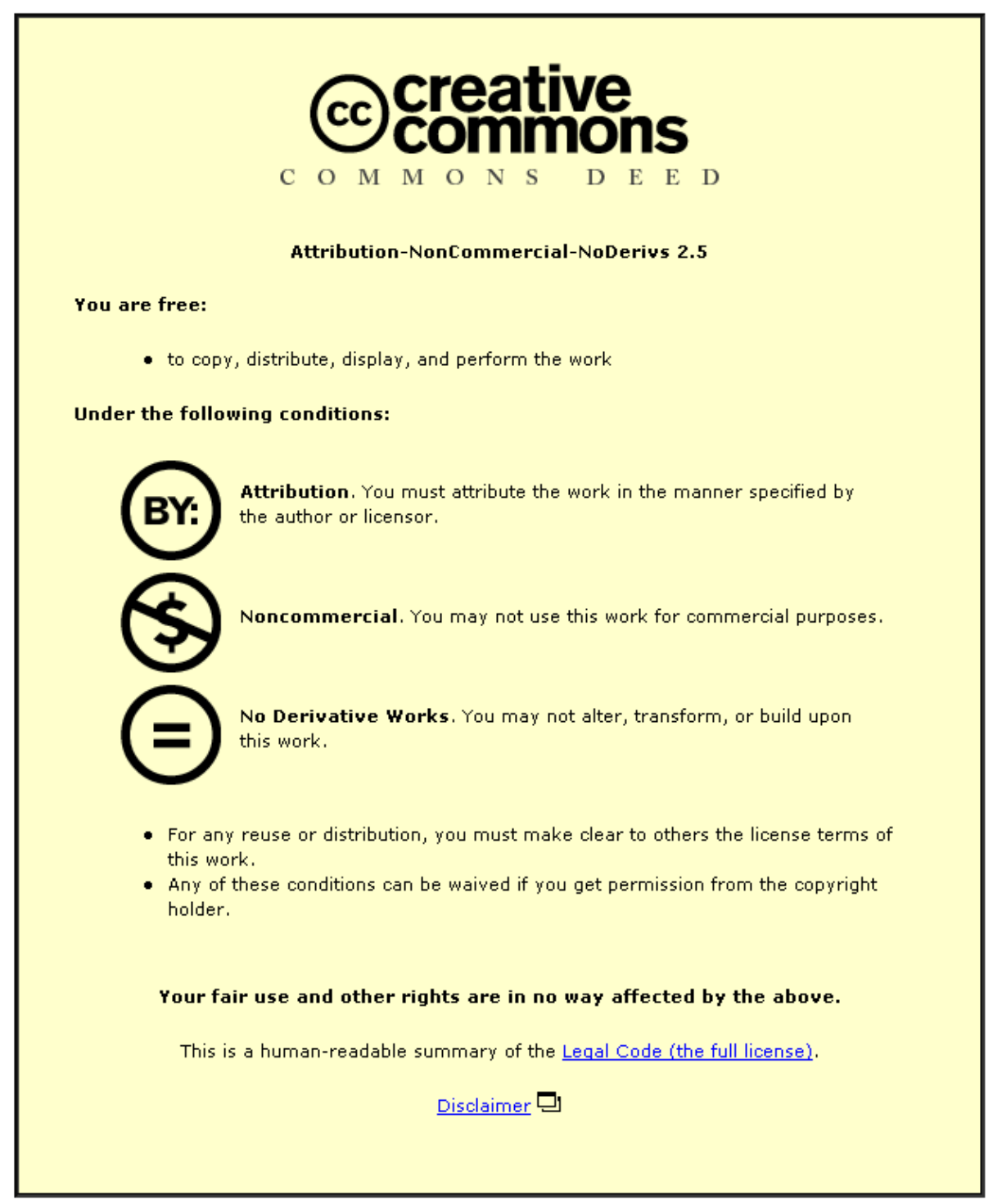

For the full text of this licence, please go to: http://creativecommons.org/licenses/by-nc-nd/2.5/ 


\section{Public-private partnerships in the water and sanitation sector}

M. Sohail MSc, PhD, FASCE and S. Cavill MSc, PhD

Following the growth, employment and redistribution (GEAR) programme in June 1996, South Africa saw an acceleration in the privatisation of service delivery. This paper reports on a study of two longer-term public-private partnerships (PPPs) in the water and sanitation sector undertaken in Queenstown and Dolphin Coast. The case studies offer important insights into a number of factors that determine the effectiveness of PPPs, including quality and quantity of services, workers, municipal tariffs for water and sanitation, customer management and impact on the poor. The case study findings are used to assess the general risks to main stakeholders involved in PPPs (the concessionaire, council and community) and to provide universal lessons on the conditions under which PPPs in the water and sanitation sector work best.

\section{BACKGROUND TO THE RESEARCH}

This paper is based on a research project that was initiated to look into public-private partnerships (PPPs) in the context of poverty alleviation. ${ }^{1-3}$ PPPs are relatively new arrangements and one of the key objectives of this research was to fill some of the gaps that exist in evidence-based reporting of the facts and issues around the impacts of PPP on poor consumers. The case studies undertaken in South Africa reveal factors that determine the effectiveness of PPPs, and thus lead to a better understanding of the conditions under which such arrangements work best.

\section{ROLE OF THE PRIVATE SECTOR IN SERVICE DELIVERY}

The PPP consists of a relationship, usually backed by a contract, in which the private sector is committed to the major responsibilities of the utility (financing, ownership, operation, cost recovery) and/or commits investment funds and shares in commercial risk, as opposed to simple contracting-out arrangements between the public sector and a private operator.

The relative merits of private sector participation in the water and sanitation sector have been extensively debated in the literature. Partnerships between government and the private sector in the area of water and sanitation are recommended for local governments as both an alternative financing mechanism and a way to improve the productivity, quality and cost effectiveness of services through changing the incentives operating in service delivery. ${ }^{4}$ The scope of private sector involvement in water and sanitation ranges from the delivery of services, maintenance of installations, meter reading, collection of service payments and data processing. The participation of the private sector in service delivery, although not necessarily ownership of assets, has been widely adopted in developed countries and advocated by donors in developing countries as part of economic reform.

Nevertheless, the water and sanitation sector is considered as the least profitable and most risky urban service sector. Water and sanitation services are more attractive to the private sector in countries with buoyant economies (and thus high concentrations of income) or in countries with high concentrations of population. Increasing service provision directly to the poor is generally considered to add risk and expense to the enterprise.

\section{THE POLICY AND LEGISLATIVE CONTEXT IN SOUTH AFRICA}

Post-apartheid South Africa inherited a massive backlog in the provision of basic services to previously disadvantaged communities. Local authorities faced the challenges of upgrading and developing previously neglected areas under their jurisdiction. The policy trend towards PPPs for water and sanitation has seen the preparation of enabling legislation for private sector participation.

(a) The Constitution of South Africa Act 108 of 1996 (especially sections 151-164) grants all citizens an equal and inalienable right to water, and requires the state to fulfil these rights. ${ }^{5}$

(b) The growth, employment and redistribution (GEAR) policy provided an impetus in both policy and practice for partnerships with the for-profit private sector, cost recovery principles and 'fiscal discipline' to meet service backlogs. ${ }^{6}$

(c) The Water Services Act 108 of 1997 confers on local governments the power to enter into contracts with private partners to provide water and sanitation services. ${ }^{7}$

(d) The Municipal Systems Act No. 32 of 2000 provides for a specific regulatory framework for municipal service partnership and local authority water bylaws that are developed by each local authority. ${ }^{8}$

(e) In response to union concerns regarding universal service coverage, wide-scale retrenchment and anti-union policies, the White Paper on municipal services partnerships ${ }^{9}$ 
makes clear that the public sector is the preferred mode of delivery.

(f) White Paper on Basic Household Sanitation in 2001 calls for universal access to basic sanitation by March 2010, with priority accorded to communities with the greatest needs.

(g) The second White Paper on water supply and sanitation policy (2002) established the need for further decentralization in the sector, limiting DWAF's role to policy and regulation. In rural areas this policy of decentralization was supported by the Masibambane program (2001-2004), the first-ever sector-wide approach linked to budget-based donor support for rural water supply and sanitation in South Africa.

\section{WATER AND SANITATION FOR THE POOR}

At the time of the first democratic elections in 1994, 14 million South Africans did not have access to clean drinking water and 21 million people did not have adequate sanitation; 14\% of South Africans had no form of refuse removal and over 20 million people did not have access to electricity. ${ }^{10}$ President Motlanthe reviewed government progress against its objectives in his state of the nation address in February 2009. ${ }^{11}$ He stated that by 2008 access to potable water has improved from 62\% in 1996 to $88 \%$ in 2008; and access to basic sanitation from 52\% to $73 \%$. Increased coverage has been facilitated by a combination of six kilolitres (cubic metres) of free water per month (40 1/capita/day for a family of five or 251/capita/day for a family of eight, cross-subsidies by way of block tariff and targeted credits available to assist poorer households, and other capital funds provided by national and provincial government (such as the municipal infrastructure investment framework). Nevertheless, approximately 6 million people are still without potable water and many more are without sanitation.

Pre-paid meters have been introduced in a number of cities in South Africa. These meters cut off water supply above the 6 cubic meter monthly limit if no payment is made. Residents of Phiri, a neighborhood in Soweto, have sued against pre-paid meters. In April 2008 the South African High Court found this practice unconstitutional, the judge stated that '25 liters per person per day is insufficient for the residents of Phiri', and ordered the city to provide free basic water in the amount of 50 liters per person per day with the option of an ordinary creditmetered water supply (instead of pre-paid) for more use.

\section{METHODOLOGY}

At the onset of the study, the literature on PPPs (and more specifically PPPs in South Africa) was reviewed. The information obtained constituted a useful database for this study.

Interviews were conducted with key informants in the Dolphin Coast and Queenstown areas. Informants included members of the municipality, including the municipal manager and other senior officials of the municipality directly involved in the PPP, ward councillors and the representatives from the operators (Water and Sanitation Services South Africa (Pty) Ltd (WSSA) in Queenstown and Siza Water Company in the Dolphin Coast).

In-depth household questionnaires were conducted in Queenstown. A total of 22 household questionnaires were completed in different wards in eZibeleni and Mlungisi.
A focus group discussion was held at the councillor's chambers of the municipality with 14 councillors representing different wards in eZibeleni and Mlungisi in Queenstown. In the Dolphin Coast area focus group discussions were conducted with consumers.

\section{CASE STUDIES}

\section{I. Queenstown}

Queenstown is the sub-regional administrative, commercial and service centre of the midlands region of the Eastern Cape Province in South Africa. It is a predominantly poor town with a population of approximately 200000 (see Table $1^{12}$ ). It comprises three distinct areas

(a) the original municipal area of Queenstown, characterised by a relatively high-income population and a busy retail centre

(b) Mlungisi, a former provincially administered township

(c) eZibeleni, a formerly Transkei administered township.

In 1989, Queenstown municipality experienced problems that affected its ability adequately to provide municipal services. There were concerns that this would lead to deterioration of the existing services and resulted, in 1992, in a concession contract between the municipal and the joint venture Water and Sanitation Services Africa (WSSA) for a period of 25 years. The Queenstown contract is an example where adjustments have been made to existing contracts during operation in order to improve services for the urban poor. The Queenstown concession contract was intended to serve white areas only (a population of 22,000) but was subsequently expanded in 1995 (following democratic elections) to service black areas - an extra 170,000 inhabitants of the predominantly low-income areas Mlungisi and Ezibeleni. WSSA, a joint venture with Group Five.

The contract includes the management of raw water supply, water treatment, water distribution reticulation, wastewater reticulation and wastewater treatment. The operator is obliged to provide, repair and replace the water and sewer networks, including new connections and civil structures, in consultation and agreement with the municipality throughout the contract duration. WSSA bears the operational costs (such as manpower, energy, consumables and chemicals) of water and wastewater management. WSSA must also meet all the prescribed standards and performance criteria specified in the contract, that is water quality standards and minimum required pressure.

Issues of public interest such as the setting of tariffs, standards and level of service are the responsibility of the municipality.

\begin{tabular}{|lc|}
\hline Monthly income: $\mathrm{Ra}^{*}$ & Population: \% \\
\hline$<800$ & 50 \\
$800-1500$ & 24 \\
$1500-3500$ & 14 \\
$>3500$ & 12 \\
\hline${ }^{*}$ I South African rand $\approx \$$ US 0.10 \\
\hline \multirow{2}{*}{ Table I. Household income distribution in Queenstown in } \\
\hline $997^{12}$
\end{tabular}


The contract provides a framework for the municipality to monitor and regulate the contract in respect of all contractual performance obligations. The municipality can impose a penalty per hour per consumer on the operator should it fail to deliver services to the required quality and availability (this penalty has been imposed once for one day's service over the last ten years). At the end of the contract, all assets - including those installed under the contract - will be handed over to the municipality.

Under this contract WSSA has full responsibility for operating and maintaining the service but does not have a direct contractual relationship with consumers. Nevertheless, WSSA developed a service charter (related to performance areas and compliance standards) that provides explicit guidelines for the provision of services.

Interviews with poor households indicated that water quality is good, meters are read regularly and bills are received regularly. However non-payment is still high (an estimated 40-45\% of households), mainly due to low incomes and unemployment in the area. Despite adopting a stepped tariff structure and six kilolitres of free basic water, residents still reported that water and sanitation tariffs are unaffordable to poor households, particularly larger households and those with big vegetable gardens. In particular, the tariffs for waterborne sewerage are beyond the majority of households' ability and willingness to pay. There is also some dissatisfaction with the household's new responsibility for leaks on private property.

\subsection{Dolphin Coast}

The borough of Dolphin Coast (BoDC), north of central Durban, consists of two parallel strips: an affluent zone on the east coast and poor residential communities in the west. The majority of households on the west side earn less than R800 (\$400) per month while the majority of households on the east earn more than R3500/per month (see Tables 2 and 3). The Dolphin Coast area depends on tourism for its survival; this results in a sharp inflow of people with great pressure on urban infrastructure and services.

In 1996 the BoDC decided to seek a private partner in its water and sanitation service in response to resource constraints. A long-term exclusive concession contract was believed to be the best option for improved management and capital investment while stopping short of divestment. ${ }^{1}$

After winning the bid, SAUR Services (the South African arm of SAUR International) formed a local company, Siza Water

\begin{tabular}{|lccc|}
\hline & \multicolumn{2}{c}{ Number of households in } & $\begin{array}{c}\text { Population } \\
\text { (estimate) }\end{array}$ \\
\cline { 2 - 3 } & $\begin{array}{c}\text { Formal } \\
\text { housing }\end{array}$ & $\begin{array}{r}\text { Informal } \\
\text { housing }\end{array}$ & \\
\hline Nkobongo & 1318 & 1000 & 9931 \\
Etete & 328 & 1500 & 7476 \\
Shakashead & 333 & 500 & 3499 \\
Formal towns & 5500 & 0 & 15400 \\
Total & 7479 & 3000 & 36306 \\
\hline Table 2. Population of Dolphin Coast according to BoDC officials & \\
\hline
\end{tabular}

\begin{tabular}{|lrrrr|}
\hline & \multicolumn{4}{c|}{ Monthly income: \% of population } \\
\cline { 2 - 5 } & $<$ R800 & R800-RI500 & RI500-R3500 & $>$ R3500 \\
\hline Nkobongo & 61 & 25 & II & 2 \\
Etete & 62 & 26 & II & 2 \\
Shakashead & 62 & 26 & $1 \mathrm{II}$ & 2 \\
Formal towns & 6 & 7 & 28 & 59 \\
& \multicolumn{5}{c}{} \\
\hline
\end{tabular}

Company (SWC), a consortium of five partners. The borough council signed a 30-year contract with Umgeni Water and SWC worth R4 million per year, whereby SWC buys water from Umgeni and distributes it to retail consumers in the Dolphin Coast area. Umgeni is involved in water management and is the largest bulk water supplier in the province of KwaZulu-Natal, South Africa. SWC has been responsible for the provision of water and sanitation services to the Dolphin Coast since 1 April 1999 (see Figure 1).

As the concessionaire, SWC was granted the right to "possess, use, operate, manage, maintain, rehabilitate, redesign, remove, improve and expand' the existing works at its own risk and cost. The company is also expected to meet prescribed levels of service that are based on affordability and to take full commercial risk by maintaining and developing the infrastructure, providing the service, billing customers and being responsible for tariff collection. BoDC, through government grants, made a considerable investment in infrastructure in the Dolphin Coast area shortly before SWC took over responsibility for the system.

The borough is responsible for determining tariffs using an agreed formula based on a five-year period. The five-year tariff

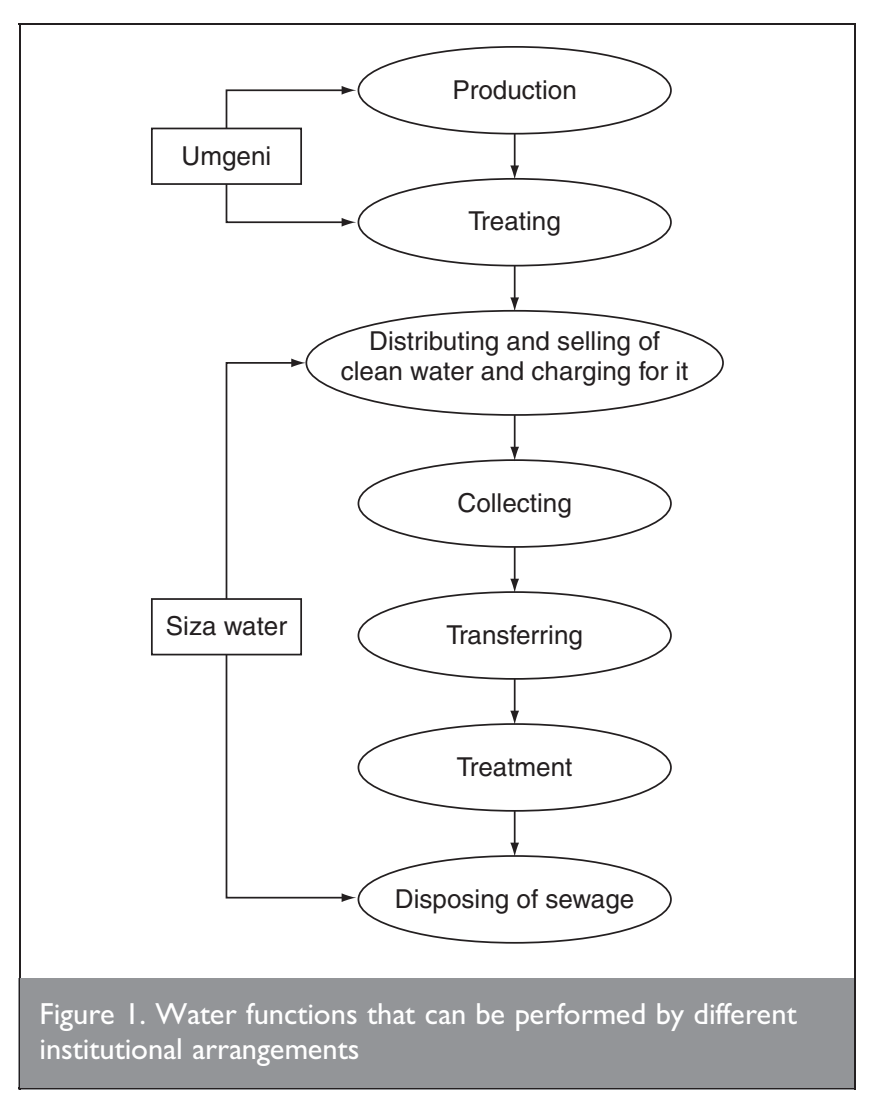


structure is reviewed periodically in line with developments taking place, including the consumer price index. SWC has no voice in the negotiation and setting of bulk water tariff.

A degree of flexibility is awarded to the private operator for devising the specific details of provision to poor users. The levels of water and sanitation services provided by SWC include

(a) level 1 service is a water dispenser (typically a Bambamanzi community standpipe pre-payment meter) with a ventilation improved pit latrine for each household

(b) level 2 service provides a 2001 tank and a septic tank for each household

(c) level 3 service is a full water connection with a flush toilet for each household.

\section{EVALUATION OF CASE STUDIES}

\section{I. Quality and quantity of service}

The basis for awarding the Dolphin Coast concession was that the concessionaire would provide a cost-effective and efficient water and sanitation service to residents. According to workers, management and councillors, frequent breakdowns occurred in the first months of operation, however, these have been drastically reduced and services were rapidly re-established after breakdowns. In the Dolphin Coast, unaccounted water (or water loss) dropped from over 30\% to $16 \%$ in a period of one year. Tariff collection rate increased from 75\% to 97\%. Three SWC customer service centres became operational with established payment procedures and a full-time community liaison officer for disadvantaged areas. An earlier report established that residents felt there had been rapid response to customer complaints, with new standpipes and house connections in disadvantaged areas and a service upgrade in other areas. ${ }^{13}$

The results from the Queenstown case study indicated a number of technical improvements since establishment of the PPP, including

(a) unaccounted water was an average of 18\% in late 2002

(b) the number of pipe bursts is approximately 0.3 bursts $/ \mathrm{km}$ per annum

(c) the number of sewer outflows is approximately 10 per $\mathrm{km}$ per annum in 2002

(d) ageing pipes have been replaced in Mlungisi and eZibeleni.

Queenstown Municipal officials reported an increase in the number of leaks fixed, attributed to the council's new rebate policy for dealing with leaks within the boundaries of residents' properties. The water accounts of residents in poor areas are checked for high consumption, an indicator of a possible leak. If a leak is detected people are asked to repair the leaks and to submit the receipt (from their plumbers) to the municipality. Once this is done, a rebate is granted to the resident's account.

\subsection{Workers}

Trade unions were engaged in the build-up to the concession in the Dolphin Coast. After the announcement of the preferred bidder in 1998, a period of negotiations with interested stakeholders followed. Negotiations covered staff, assets, investments and other issues, and Dolphin Coast municipal staff were kept informed of all these deliberations. According to councillors and officials, unions presented the greatest obstacle to the borough initiative and the contract had to make significant accommodation to union demands. Opposition was finally overcome through high-level intervention from ministers and ANC leaders. The concessionaire was obliged to employ local people from the Dolphin Coast area and use local materials wherever possible; the contract compels the use of labourintensive techniques where feasible, although there has been criticism of the distribution of these jobs. An undertaking not to terminate employment and to permit continued union activities by workers was key to the concession.

Workers at SWC are divided over the change from municipality to the private sector. Although there is appreciation of the training that has been provided (driving licenses, literacy training and module 2 plumbing courses), there is also criticism that these new skills are not sufficiently used or rewarded.

In the Queenstown contract a consultative process took place with stakeholders, including civic associations and organised labour. All previous municipal employees opted to join the concession company. There have been minimal labour disruptions since the commencement of the contract. More job opportunities have been created via community-based construction programmes undertaken to extend services and infrastructure to previously unserviced areas. Although workers appreciated the training that has been provided (driving licenses, literacy training and plumbing courses), there was also criticism that these skills were not sufficiently used or rewarded.

\subsection{Credit control}

In Queenstown, ward councillors have become involved in credit control and in arranging the reconnection of customers who have been disconnected. Councillors and customers together negotiate an arrangement to pay arrears in order to avoid disconnection. The new credit control policy has reportedly had a positive impact on the rate of payment for services and has also reduced the number of disconnections in the municipality. The council also developed an incentive scheme to reward individuals who pay their outstanding accounts with credit on the amount that has been paid.

However, in the Dolphin Coast it was reported that some people who have household connections are reverting back to using standpipes because they cannot afford their bills. In discussion with council officials and the management of SWC, it was stated that communities did not understand the implications of full water and sewerage connections before occupying their houses.

\subsection{Customer management}

Despite not being contractually liable for customer management, in the Queenstown PPP WSSA has taken a number of steps to assist with customer management. For example, the company planned to set up a toll-free telephone line as well as providing funding to the municipality for the salaries of staff responsible for handling complaints regarding water and sanitation. However, the residents of eZibeleni and Mlungisi interface largely with ward councillors and other municipal officials when they have queries or complaints and the ward councillors then contact WSSA. One councillor said 'if there is a pipe burst in the middle of the night in my ward, I can contact a senior official at WSSA directly'. Overall, residents stated that they found it easier to deal with their councillors than dealing with a private company. 
Customer service offices, which serve as contact points between customers and SWC, have been opened in Dolphin Coast. In addition, there is a telephone help line and newsletters have been distributed by SWC with customers' bills. Two full-time community liaison officers from the BoDC deal with various community issues including water and sanitation. They are responsible for communication with the communities through ward committees. Other communication channels used by SWC to keep in touch with its stakeholders include community notice boards in English and Zulu, face-to-face communication, posters and flip charts, schools liaison, functions and activities, regular contact with the BoDC and communication with government and other organisations. Furthermore, the Dolphin Coast contract compels the concessionaire (at the time of submitting an annual report on service levels to the council) to publish a summarised extract from the annual report on service levels and inform customers of its existence.

\subsection{Municipal tariffs for water and sanitation}

The main danger to the poor under PPP water and sanitation provision is that tariffs and/or connection charges become unaffordable, meaning that this group does not gain access to better water and sanitation services. $10 \%$ of income is generally regarded as the maximum amount a household would be prepared to allocate to service payments.

In 2000, Queenstown residents were charged for a minimum of 100001 at R2.42 per thousand litres. This meant that residents who consumed anything between 0 and 100001 were still required to pay $\mathrm{R} 24 \cdot 20$ for their water. This tariff structure changed as a result of the government's free basic water policy introduced after 2000. Currently, fixed monthly charges plus a rising block rate apply to all consumers who consume more than 60001 of water per month; households consuming less than 60001 per month pay nothing. The major advantage of this system is that it reduces the cost of service provision to small users. When one compares what people paid for water in 2000 with current costs, then the present tariff structure benefits those who consume less than 210001 per month. People consuming more than 210001 are paying more for water (in real terms) than they did in 2000 (see Table $4^{14}$ ). Tariffs are cheaper for poor residents and a rebate of $40 \%$ is offered for households earning less than R1300 per month. However, levels of non-payment for water and sanitation remain high due to the high levels of poverty and low levels of employment in the municipality.

The whole of the Dolphin Coast has only 4500 customers (households). Average consumption per person in the better-off

\begin{tabular}{|c|c|c|}
\hline $\begin{array}{l}\text { Consumption: } \\
0001\end{array}$ & $\begin{array}{l}\text { Consumption } \\
\text { charge: } \mathrm{R}\end{array}$ & $\begin{array}{c}\text { Basic charge: } \\
\text { R }\end{array}$ \\
\hline $0-6$ & 0.00 & 0.00 \\
\hline $6-20$ & $2 \cdot 26$ & 18.38 \\
\hline $21-50$ & $2 \cdot 26$ & 28.88 \\
\hline$>51$ & $3 \cdot 15$ & $41 \cdot 00$ \\
\hline
\end{tabular}

eastern area is $2601 /$ day and about 471 /day in the poor western area. Residents pay for the amount of water consumed, a standard charge built into water invoices and a sewerage tariff based on the volume of water consumed. In the Dolphin Coast, a three-tier system is in operation (Table $5^{14}$ ). The first 100001 is technically 'free', but limited to consumers with household connections (i.e. not those who use standpipes), although every connected household customer pays a standard connection charge (approximately R24·60).

The question of fixed charges is a provocative issue in the townships and is a heavy burden on the urban poor. The increase in costs under private provision has led residents to seek out alternative means, including using river water in the rainy season to lessen their costs, which is not beneficial to the user or the operator.

Sanitation is a particularly difficult service to provide under a PPP. Respondents in both case studies were dissatisfied with the increased sewerage costs that resulted from the PPP.

Nevertheless, despite being unaffordable, respondents showed considerable resistance to accepting anything less than fullservice options, whether it was affordable or not.

\subsection{Impact on low-income communities}

In the Dolphin Coast, key pro-poor elements include tariff and operational issues, an empowerment component, social development and staff training. The Siza Water youth and community development fund was set up with the primary objective of "uplifting and development of the youth and community within the concession area'. From its inception, advocates of the Dolphin Coast concession stated that those who could not pay for water would be provided for. A clause in the contract stipulates that the council and the concessionaire shall agree on methods whereby funds and/or other support are given to assist indigent families to pay for the supply of basic water services. Such assistance may be given by crediting

\begin{tabular}{|c|c|c|c|}
\hline & \multicolumn{3}{|c|}{ Tariff: $\mathrm{R}$} \\
\hline & 1998/1999 & $1999 / 2000$ & $2000 / 2001$ \\
\hline Site-metered (basic charge per month) & $20 \cdot 00$ & $20 \cdot 00$ & $24 \cdot 60$ \\
\hline $0-100001$ consumption & 0.00 & 0.00 & 0.00 \\
\hline II-35000 I consumption & $2 \cdot 23$ & $2 \cdot 45$ & $2 \cdot 74$ \\
\hline$>350001$ consumption & 2.92 & $3 \cdot 15$ & $3 \cdot 60$ \\
\hline Water dispensers per $000 \mathrm{I}$ & - & 3.53 & 3.94 \\
\hline
\end{tabular}




\begin{tabular}{|c|c|c|}
\hline Risk to concessionaire & Risks to councils & Risks to community \\
\hline Non-payment by consumers & Breach of contract by concessionaire & Increases in tariff rates to consumers \\
\hline $\begin{array}{l}\text { Unreasonable bulk water tariff } \\
\text { increase }\end{array}$ & Revenue loss & $\begin{array}{l}\text { Cut-offs for non-payments and liability for } \\
\text { reconnection fees }\end{array}$ \\
\hline Union action & Poor service to residents & Cherry picking of investments \\
\hline Challenge of providing the lifeline tariff & Unpopularity & Accountability to the community \\
\hline $\begin{array}{l}\text { Municipal area requiring a huge capital/ } \\
\text { infrastructure outlay }\end{array}$ & Unable to renegotiate contract & $\begin{array}{l}\text { Reduced access to alternatives such as community } \\
\text { sources and informal sector provision }\end{array}$ \\
\hline
\end{tabular}

customers' accounts, or by the provision of vouchers, coupons or tokens. In fact, the study team found that none of these provisions appeared to have been implemented. An underlying barrier to the extension of formal services to illegal settlements is land tenure, and regularising land tenure could be considered as an appropriate role for the public sector within the PPP.

The Queenstown PPP case study indicated that, while the quality of supply had improved significantly at a broad scale, the improvements had accrued largely to the municipality (improved maintenance and reduction in aged pipes) and had not been felt by poor households who are unhappy with tariff issues and the way leaks on private property are dealt with.

In general, an examination of the issues related to the contractual stage of the PPP process has shown that the needs of poor users do not appear to be taken into account when the initial decision to engage in a PPP arrangement is reached.

\section{CONCLUSION}

Following the GEAR programme in 1996, there was a visible acceleration of privatisation in service delivery in South Africa. While PPPs can work well, implementation of a concession poses a number of risks to all. There are clear advantages in spelling out these risks at an early stage of such an arrangement so that the various stakeholders are aware of the pressures that exist and are therefore more likely to approach negotiations more realistically. These risks are summarised in Table 6.

Mechanisms by which risks to stakeholders can be mitigated within PPP arrangements should be given further consideration. A review of the concessions in Queenstown and Dolphin Coast (see Table 7 for a comparison) concludes that for similar

\begin{tabular}{|c|c|c|}
\hline & Dolphin Coast & Queenstown \\
\hline $\begin{array}{l}\text { Information and participation } \\
\text { prior to the concession }\end{array}$ & $\begin{array}{l}\text { Communities were involved, but respondents } \\
\text { felt that there were either not involved or } \\
\text { only involved up to a certain level }\end{array}$ & Communities did not feel consulted \\
\hline Training of workers & Workers were trained & Information not available \\
\hline Remuneration of workers & Static pay for last 2 years & Information not available \\
\hline Water supply breakdowns & Used to be a problem, now under control & $\begin{array}{l}\text { Quality and quantity of supply reportedly } \\
\text { improved }\end{array}$ \\
\hline Equipment & Adequate & Information not available \\
\hline Tariffs & Respondents felt they are too high & Dissatisfaction with tariffs, felt to be unaffordable \\
\hline $\begin{array}{l}\text { Relationship with local } \\
\text { government }\end{array}$ & Good & $\begin{array}{l}\text { Mediation by ward councillors resulted in better } \\
\text { credit control policies }\end{array}$ \\
\hline $\begin{array}{l}\text { Relationship with concessionaire } \\
\text { management }\end{array}$ & Suspicious & Suspicious \\
\hline Relationship with councillor & Working well & Working well \\
\hline Water quality & $\begin{array}{l}\text { SWC claim it is very good, but residents feel } \\
\text { it is questionable }\end{array}$ & $\begin{array}{l}\text { Residents reported an improvement in water } \\
\text { quality }\end{array}$ \\
\hline Community fund & $\begin{array}{l}\text { SWC claim community fund is uplifting the } \\
\text { community. However, the community does } \\
\text { not acknowledge this }\end{array}$ & Information not available \\
\hline Concession status & $\begin{array}{l}\text { Working well but there is room for } \\
\text { improvement }\end{array}$ & $\begin{array}{l}\text { Overall improvement in service delivery, } \\
\text { particularly around the area of quality of service }\end{array}$ \\
\hline Unionisation & Unions overcome initial problems & Information not available \\
\hline
\end{tabular}


ventures to succeed there is the need for

(a) a supportive, consistent legal and regulatory framework, for example, the Municipal Systems Act that was developed to build uniform regulation nationally

(b) coordination between national government and other stakeholders

(c) financial and technical assistance to local authorities

(d) a forum to resolve issues, e.g. on labour should be established

(e) strong political will

$(f)$ evenly matched power to negotiate between council, concession, and community ${ }^{15}$

\section{ACKNOWLEDGEMENTS}

This paper is based on two studies of the impact of PPPs in the provision of water and sanitation services on poor residents. Palmer Development Group (PDG) investigated the PPP in the Queenstown transitional local council (TLC) and the Institute for Social and Economic Studies (ISES) of the University of Durban Westville studied the Dolphin Coast concession. Both studies were commissioned by the Water Engineering Development Centre (WEDC) at Loughborough University in 2000. In late 2002, PDG was commissioned to conduct a follow-up study on the Queenstown partnership to determine if any changes had been made that affect the way in which poor residents in Queenstown experience water and sanitation delivery delivered through the partnership. The research was funded by the Department for International Development (DFID).

\section{REFERENCES}

1. Sohall M. (ed.) Public Private Partnerships and Poor. Case Study: Dolphin Coast Water Concessions, Dolphin Coast, South Africa. Water Engineering Development Centre, Loughborough, 2002.
2. SoHAIL M. (ed.) Tools for Pro-Poor Municipal PPP. Margarf, Wiekersheim, 2004.

3. Sohall M. (ed.) Public Private Partnership and the Poor. Case Study: Revisiting Queenstown, South Africa. Water Engineering Development Centre, Loughborough, 2005, pp. 1-26.

4. IMIESA, 1999, 24, No. 2.

5. Republic of South Africa. The Constitution of the Republic of South Africa. Government Printer, Pretoria, 1996.

6. Republic of South Africa. White Paper on Growth, Employment and Redistribution. Government Printer, Pretoria, 1996.

7. Water Services Act 1997.

8. Republic of South Africa. Water Services Act 1997. Government Printer, Pretoria, 2000.

9. Department of Provincial and Local Government. White Paper on Municipal Services Partnerships: A Strategy to Ensure Universal Access to Municipal Services during this African Century. Government Printer, Pretoria, 2002.

10. RePublic of South Africa. White Paper on the Reconstruction and Development Programme. Government Printer, Pretoria, 1994.

11. State of the nation address. http://www.info.gov.29/ speeches/2009/0902061106001.htm

12. Palmer Development Group. Municipal Infrastructure Investment Guidelines: Queenstown Case Study. PDG, South Africa, 1998.

13. IMIESA, 2000, 26, No. 8.

14. Proposed Tariff of Charges 2000/2001. BoDC.

15. Kotze R., Ferguson A. and Leigland J. Nelspruit and Dolphin Coast: lessons from the first concession contracts. Development Southern Africa, 1999, 16, No. 4, 623-648.

What do you think?

To comment on this paper, please email up to 500 words to the editor at journals@ice.org.uk

Proceedings journals rely entirely on contributions sent in by civil engineers and related professionals, academics and students. Papers should be 2000-5000 words long, with adequate illustrations and references. Please visit www.thomastelford.com/journals for author guidelines and further details. 